\title{
The being genderless of public sphere and sport
}

\section{Murat YÜKSEL}

Ordu University, Department of Sociology, Ordu, Turkey.

Address Correspondence to M. Yüksel, e-mail: bdmurat81@hotmail.com

This paper was presented (oral presentation) at the International Balkan Sport Sciences Congress held in Bursa on 21-23 May 2017.

\begin{abstract}
In the public sphere is a common living sphere open to the participation of individuals. It is seen that the public sphere where each individual is involved with different purposes and can express his ideas freely is rapidly becoming genderless in modern societies. The aim of this study is to reveal how being genderless of public sphere is reflected in the sporting area, which is one of the social institutions. The research carried out in Istanbul and was applied to a total of 1000 people, 526 of them are women and 474 of them are men, by random sampling technique. According to findings of the research, it was found a high significant relationship between gender and "It is not right that women and men do sports with together" and "Adult girls and women should not do sports". Those who answered the question as "I do not agree" was 59\% of women and $69 \%$ of men. In the second question, the rate of those who do not agree with the opinion that women should not do sports is $95 \%$ for women and $91 \%$ for men. According to this, it is seen that a transformation was created from a structure that women were not seen proper to do sports to a structure that both women and men do sports and both women and men included in some sports that they took place together. As a result, it is seen that the public sphere has also become significantly genderless.
\end{abstract}

Keywords: Being Genderless of Public Sphere, Public Sphere, Sport

\section{INTRODUCTION}

In order to evaluate the relationship between being genderless and the sports of the public sphere, it is necessary to determine the gender relations throughout history, the historical and social factors affecting these relations, and the breaking or turning points in these relations in the process. In other words, when we started from the statement that "present time feeds from whole of historical evolution that humanity experienced till today" by Braudel (2014) we have to search the social gender relations and traces of these changes experienced in these relations in the history. In addition, in order to better understand the continuity of these differences from the past to the present, detailed analysis the effect of social structure on the position of women and men, the changing roles of women and the factors affecting it, especially the body of the woman restructured in the capitalist world or the consumer society and role of mass media on fixity of perceptions.

The discussion of gender roles in the West started with the change of family structure and the ease of house works with the production of technological tools and equipment, the loss of meanings of traditional roles attributed to women such as - the mother / housewife - and as the result of women participation in economical life, the public sphere became a sphere that shared by both gender equally. On the one hand, while there have been important changes in the men's fixed social roles, the public sphere has started to turn into an "asexual" area where women are more involved (3).

The first known study on sports tourism is the study done by the Central Council for Physical Recreation in 1966, in which sport is included in tourism (13).

Sport has also undergone significant transformations in this process and has emerged as a unique phenomenon of modernity and became a practice that caused to sexist structuring of public sphere and then contributed to being genderless process of public sphere. In the early days of modernity, while women make efforts to present in the public sphere, sport has emerged as a menspecific practice (3). However history, in general, was for the benefit of women and still is in the every stage of the social life, specially in sports area.

The gender differences that we encounter at every stage of social life have been manifested in 
sport which is one of the social institutions for a long time. In Ancient Greece, sports was the practice that mostly men participated in until middle of $\mathrm{XX}$. century. However, from second half of XX. century, sports became a massive activity and in the later of 1960s, it was seen that men who did not talk about sports or participate in sports conversations were deemed as psychiatric patients (44). The massification process of the sports did not occur on a single gender or a class, transformed a activity that everyone participated in regardless age, gender or status (13). Therefore, in this process, women have started to participate in sports activities more and more each passing day.

Moreover, in today's world where visuality comes to forefront, a body image is imposed by the mass media, where the body is standardized and the ideal women body is reduced to a certain size. In this process, the emphasis on the aesthetic aspect of the women body has increased continuously (29), thus women have employed every method to have this idealized body. Woman who did not take care of her body while living in her own traditional family environment, began to show more interest in sports to have the ideal body created for herself, her cosmetic products to be beautiful, with her existence in public sphere in modern life.

Taking place of women as a subject specific to modernity and sport as phenomenon specific to modernity and examination of how changing social structure or public sphere reflected to social gender relations on especially sport, a firm institution in accepting women in its structure is important since it reveals the transformation experienced in public sphere.

\section{Public Sphere}

The distinction of public sphere and private sphere based old-time (8), public sphere concept relatively related to newer and development of civil society. While some studies on public sphere draw attention to the decline of public people and some studies on public relations and public opinion, especially feminist studies have questioned the public and private distinction on the axis of gender and made important contributions to the field (35).

The public sphere is a place where everyone is involved and where individuals are united in a coherent manner, without a limit on the participation of people (5). According to another definition (36), the public sphere is a democratic area where people are equal, free, and they can express their thoughts. As it can be inferred by these definitions, concepts such as democracy, the terms 'freedom, equality and plurality' indicate the basic characteristics of the public sphere.

The modern world of today is a world that the public sphere has undergone a significant change. This process of change takes place as two directions. First of all, it is stated that the relations in the public sphere suggested by theorists such as Sennett (2016) Riesman (2016) and Arendt (2013) have changed and in a modern urban environment, people experience a process that has been isolated in crowds without communicating with each other, without even greeting each other, and the become aliens in the life that they have created. In other words, we live in a world that the public people collapsed or the publicity that people have previously had declined significantly. From another point of view, especially from the point of view of the genders to the process, it is clearly seen that the public sphere has turned into women's favor.

On the other hand, Habermas (2014) discusses how publicity, means public or public opinion, undergone a transformation as a place rather than public sphere in his work named "The Structural Transformation of the Public Sphere". Habermas draws attention to the behavioral patterns in the public sphere through concepts such as public and public opinion and how they are changing. According to Habermas, publicity is important due to its relationship with democracy. Habermas claims that publicity can be developed even though publicity has undergone a structural transformation and eventually collapsed due to the influence of various factors. According to Habermas, this process will effect the participation of all sectors in the public sphere due to the equal, open and transparent relations that emerged with the public's influence in the public sphere are associated with the democratization process of the society. The relationship between the being genderless of the public sphere and sports can be evaluated both in the democratization of the society and in framework of redevelopment of publicity with increasing the participation of women in the sport.

The biggest objections to keeping women away from the public sphere, based on the distinction between the public sphere and the private sphere, came from the feminists. Feminists who think that the sexist structure of social life is not a natural but a 
socio-cultural construction, have been in an intense struggle for women to take part in the public sphere on an equal with men. This struggle accelerated especially since 1960s, and significant gains were achieved in terms of gender equality $(2,15)$. Feminists and critical theorists, gave a comprehensive critique for the social position of women, brought many criticisms of the mendominated structure of the sports field $(45,4)$ and made important contributions to the equal representation of women and men in the field of sports. In other words, feminist researches have also contributed significantly to the being genderless of the public sphere.

\section{Being Genderless of Public Sphere}

Anthropological data show that women-men relationships appear in different forms from food collecting society to food producing society, from industrial society to after industrial society. In some societies, women are stronger, but in the other societies, men are stronger. However, in some societies, women and men are equal to each other. Despite these different social manifestations, it is clear that there is a gender-based division of labor (27). In this context, women have a more limited area - predominantly in and around the house - and certain jobs - food collection, child care, etc. - men act in a wider area and have a voice in many areas, particularly in the economy (37).

Although the Industrial Revolution is a milestone for women existing from the private sphere to the public sphere, they have not been that visible for a long time in the modern public sphere which is in men hegemony (30). Gender relations that are known to exist until the Industrial Revolution and that do not pose any problems, in other words, the complementarity relationship between women and men has transformed inequality in the West especially after the Industrial Revolution and become a source of conflict between women and men (2). Since the 1950s, with the influence of the second wave feminist movements, women whose attributed gender roles began to change, became more visible in the public sphere and began to bring more powerful and vocal criticism towards the fixed patriarchal structure (9). In addition, within the changing social structure of today, job and education opportunities have increased and as a result women have begun to feel their presence in the society more.
The struggle of feminist movements for the equal participation of women in the public sphere or in every stage of social life still significantly continues today. Throughout history, the woman who has been passively living in her private sphere as a "housewife", has now existed as a subject or an individual through the influence of feminist movements and continue their existence in history stage with having new roles such as as "scientist", "business woman" and "sports woman" further to traditional gender roles (3).

Even though it does not follow a parallel course with the being genderless of the public sphere, being genderless of the sport is unique to modern society. Being genderless of sport in this framework refers to the participation of women in sports at a rate close to men and some sporting practices are done together with men and women. Starting from the the phenomenon of being genderless of public sphere increases especially in the mass sports and towards the upper layer, and the middle and lower class of the society elaborate on practices of super class reality, it can be claimed that it will increasingly become widespread (4). Nowadays, it is seen that women-specific competitions are organized in both mass sports and elite sports.

\section{Being Genderless of Public Sphere and Sport}

Women have made significant efforts to take part in the sports field on an equal to men. To break the men-dominated nature of sports and to get a place in it was not easy, and it was necessary to wait for a long time. To briefly look at what happened in this historical process also carries importance on understanding how it put up a fight to get the point where it is today.

The woman, who could not go on the stage of history as an individual for a long time, could not find a place in the sports field where men hegemony was clearly seen. There are several reasons why women cannot be involved in this field: myths about the physiological and psychological effects of competitive sports on women, the reflection of the inequality of opportunity that they encounter in every aspect of the social life to the sport and the factors that women are scarcely present in the sporting organizations are combined with the patriarchal thought and kept away women from sports field for a long time (16).

In Ancient Greece, only the first Olympic games were organized, only independent men took 
part in the competitions. During this period, the men body is exalted as a symbol of power and resilience in scope of Greek ideals with various reasons (military service, etc.), and sport is the most important means for reaching this idealized men body $(22,31,40)$. It is forbidden for women to participate actively in competitions and even they watch the events from tribune (41). It can be said that the period of antiquity is a period in which women do not involve sports.

The similarities of gender relations in the field of sports in Ancient Greece, it is possible to trace the modern sport that was born in England in the XIX century. In this period, sport is seen as an activity that only men participate in the West $(13,46)$, as in the ancient period. In addition, men domination is clearly seen in both school sports and leisure activities in the UK. It is seen in the empirical researches that this condition continues without much change until the second half of the XX century (26). In other words, the sport that is specific to modernity, especially when it first emerged, excluded women and it was built by men and a significant indicator of man's power over women as in all public spheres $(34,43)$.

The first was an event in the 1896 modern Olympic games, which included only privileged European and North American men elite athletes (47). Pierre de Coubertin, the founder of modern Olympic games, believed that only men can participate in the Olympic Games (32). Women were not allowed to participate in many official sports competitions in 1912 until they were allowed to participate in athleticism and swimming competitions in 1912 (23). It is seen that the thoughts of Coubertin, a French, on participation of women in sports are reflection of social gender relations which present in French society.

In the sports field, men's more powerful position than women is seen in the United States of America, one of the modern societies (14). Some research conducted in the 1920s and 30s in the United States is a time period that they claimed even women were among them- that sport is harmful for women and women should not participate in sporting activities. However, the aim of all these researches and efforts are to prevent women existence in public sphere (34).

From the last quarter of XX century, in Northern America, factors such as establishment of teams specific to women and their participation in various programs, regulations made for prevention of social gender inequality- Title IX- women movements and non governmental organizations, conferences, health and fitness movements and interest of media in women sport (12) provided significant importance on participation of women in sports. Especially, by means of the IX Title of the law adopted in education field in 1972, significant gains against gender discrimination were achieved in sports and from this period, women organized sport organization more and leagues that they involved in were increased and they organized championships in many branches. They also participated in various sports institutions as experts in sports (20). 40 years after the adoption of the law, women's participation in sports increased by $800 \%$ and the number of women athletes increased to 2.8 million (1). After these practices, the number of members of the Association for Intercollegiate Athletics for Women (AIAW), established in 1971, was 278, and in 1979 the number of members increased to 970 (25). Notably legal regulations, the interest of society, generally women, in equal representation has increased, the participation of women in sport has increased at same rate.

While there these changes in the relationship between gender and sport in the West, despite some differences in Turkey which is a country that its direction turned towards the West, a similar condition appeared for us. Turkey, as a modernizing country, towards the end of the XX century, women's participation in sport was relatively low compared to the modern West.

In Turkey, the participation of women in sports, some differences arisen from the culture draw attention. In the research conducted by Fasting and Prister (1999) on participation of women in sports in Turkey, it is seen that factors such as social status and residence place, importance of success in school, consideration of sports as men-specific activity, heaviness of working conditions, importance of family, women do not consider sport as fun, perception of body, beauty and being covered negatively effect participation of women in sports.

Muslim men and women in Turkey do not think that their religion prevents their participation in sports, (19), especially Islamic countries where participation of women in sport and sport institution low, religious beliefs play important role $(21,48)$. At this point, the boundaries drawn by religion for both men and women are one of the 
biggest obstacles to participation in sport (3). However, the fact that sports fields and facilities are constructed in such a way that both genders can do sports or organizing programs specific to women further increases the participation of women in sports.

A research conducted in Istanbul (49) can be considered in this scope and in this point, it is necessary to emphasize the points specific to Turkey or cities. According to the results of the study, when we look at swimming sport, we see that women are more proportionately (M: 43\%, W: $64 \%$ ). In the same way, it is seen that women are more in fitness sport (M: $4 \%$, W: $13 \%$ ). In terms of socio-cultural values, the interest of women, have a different history than Western countries, in swimming sport is noteworthy. The folkways, customs and traditions within the social structure have a great effect on human behavior. At this point, it is one of the most important factors that the sports facilities of the local administration and programs specific to women are the most important factor in showing women's interest in swimming.

As a social institution, sports can give some ideas about the structure of society. Elias's (2008) statement that $\mathrm{o}$ "recognizing the sport is to understand society" means that you can learn about that society by looking at the sporting situation of a that society or the sport they do. The participation of women in sport in a society is an indication of the development of the society or total opposite. Therefore, women's participation in the sport in a manner of modern society has particular importance. Women appeared in history stage with the Industrial Revolution as an actor and the period when the modern sport began to develop in compliance with each other. From the beginning of modernity to the present day, women have felt her existence more in the sports field and women have become more visible in the education institutions, in many national and international sports organizations - especially in the summer and winter olympic games. The apparent increase of women in the sport under men hegemony is also an indicator of the change in the historical depth of gender, physicalness and power relations.

In the XXI century society, in the break of these fixed perceptions, women's entering into work life, increasing their education levels, being more visible in public, having their problems expressed through various platforms and supporting the feminist movements have accelerated this process of change.

Today, it is seen that women's participation in the sport had significant distances, although not yet to be compared with men. Although the fixed perceptions pertaining to women's participation in the sport have not completely disappeared, it is observed that they have started to change. Women have once again been competing in men, beyond being visible in the sporting field that was only under the control of men. It is possible to see women in many sports branches where we are not accustomed to seeing them or only men are competing (50).

\section{MATERİAL \& METHOD Research Method}

The study was conducted with the survey technique which is one of the most widely used quantitative research methods used in literature review means examination of written sources such as books, articles, magazines etc. and data collection from first sources. The study was conducted by random sampling technique.

\section{Purpose of Research and Theoretical Framework}

The aim of this study is to reveal how being genderless of public sphere is reflected in the sporting area, which is one of the social institutions.

The public sphere is a common living sphere open to the participation of individuals. It is seen that the public sphere where each individual is involved with different purposes and can express his ideas freely is rapidly becoming genderless in modern societies. The process which started with the entry of women into working life, especially with the Industrial Revolution, shows its effect in every field today. Examination of how being genderless of public sphere, in other words, women are more visible in public sphere reflected to sport field which is one of social institutions create the theoretical framework of this study. Relationship between being genderless of public sphere which is examined in the first chapter of the research and sport will be evaluated in the discussion and conclusion chapter with the findings of applied research findings.

\section{Universe and Sampling}

The mass of the universe of research consists of people above the age of 15 , who do not have an athletic identity (who are amateur or do not do 
professional sports) but do sports and do not. In other words, the so-called "mass athlete" who does not make sports as a profession or to earn money, but for health, fitness, entertainment, etc. purposes constitute the universe of the research.

The The research carried out in Istanbul and was applied to a total of 1000 people, 526 of them are women and 474 of them are men, by random sampling technique.

\section{Survey Form and Application of the Research}

During the application process of the study, general questions were asked to the participants who agreed to participate in the study, including their gender, with a total of 10 problems. Afterwards, a survey form includes questions on sports was applied to the participants. The survey started to be applied in June 2012 and was completed in October of the same year.

\section{Analysis of the Research}

The data were evaluated by the researcher on the computer by the statistical program. Chi-square analysis was used to determine the relationships between variables in statistical analysis.

\section{Hypothesis of the Research}

With being genderless of the public sphere, the sports field has also become significantly genderneutral.

\section{INTERPRETATION of ANALYSIS \& FINDINGS}

The relationship between gender and "It is not right that women and men do sports with together" is shown in Table 1. There was a high significant relationship between them. Those who answered the question as "I do not agree" was 59\% of women and $69 \%$ of men. Although women seem more conservative than men, almost $60 \%$ of women see no harm in women and men can do sports together is the important indicator of being genderless of public sphere. What is more remarkable at this point is that almost $70 \%$ of men, who have held the sports field for a long time and whose sovereignty in this area have been severely shaken, support the women and men to do sports together, which is the more striking indicator of being genderless, experienced in public sphere.

Table 1. Relationship between gender and "It is not right that women and men do sports with together"

\begin{tabular}{|c|c|c|c|c|}
\hline \multirow{4}{*}{ 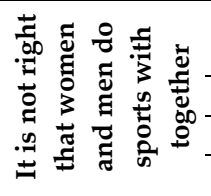 } & & $\begin{array}{c}\text { Women } \\
(\%)\end{array}$ & Men (\%) & $\begin{array}{c}\text { Total } \\
(\%)\end{array}$ \\
\hline & I agree & 33.3 & 24.7 & 29.2 \\
\hline & I am & 7.5 & 6.8 & 7.1 \\
\hline & I do not agree & 59.3 & 68.5 & 63.7 \\
\hline
\end{tabular}

Turk J Sport Exe 2018; 20(3): 310 - 317

๑ 2018 Faculty of Spart Sciences, Selcuk University

\begin{tabular}{rrrr}
\hline Total & 52.5 & 47.5 & 100 \\
\hline $\mathbf{X}^{2}=9.672$ & S.D: 2 & $\mathbf{P}=0.008$ \\
\hline
\end{tabular}

The relationship between gender and "adult girls, women should not do sports" is shown in Table 2. There was a high significant relationship between them. According to the table, the rate of those who do not agree with the opinion that women should not do sports is $95 \%$ for women and 91\% for men. According to the findings, it is clearly seen that the public sphere has been genderless in a serious breed. In other words, it can be said that the fixed perceptions pertaining to the participation of women in the sport have broken to a great extent. The we created according to this was supported.

Table 2. Relationship with gender "Adult girls, women should not do sports"

\begin{tabular}{|c|c|c|c|c|}
\hline \multirow{5}{*}{ 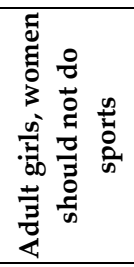 } & & $\begin{array}{c}\text { Women } \\
(\%)\end{array}$ & Men (\%) & $\begin{array}{c}\text { Total } \\
(\%)\end{array}$ \\
\hline & I agree & 3.2 & 5.7 & 4.4 \\
\hline & I am undecided & 1.3 & 3.0 & 2.1 \\
\hline & I do not agree & 95.4 & 91.4 & 93.5 \\
\hline & Total & 52.6 & 47.4 & 100 \\
\hline & $X^{2}=6.971$ & S.D: 2 & \multicolumn{2}{|c|}{$\mathbf{P}=0.031$} \\
\hline
\end{tabular}

\section{DISCUSSION \& CONCLUSION}

Sport has been one of the most rigorous institutions to accept women in its structure throughout history. In other words, it is one of institutions that women-men inequality is most clearly seen. However, the social macro transformations that have experienced socially caused the woman to leave her private sphere and increase her presence in the public sphere even more. In the early days, despite the institutions such as sports, especially politics, have made discourses and actions that keep women away from them, this resistance has been severely broken in time although not completely, and women have found place for themselves more in the field of sports each passing days.

The results of the research show that the reflection of the being genderless of the public sphere in the sport field is parallel to this social transformation. Today, it is seen that a transformation was created from a structure that women were not seen proper to do sports to a structure that both women and men do sports and both women and men included in some sports that they took place together. In other words, it is now normal for women to do sports together as men or with men. 
While several research on women's participation in sports have indicated that sport has become a tool for women from the private sphere to the public sphere $(11,6)$, there are other studies have indicated that $(18,38)$, women have started to take place even though they are few compared to men as such taking part in women's boxing, weightlifting, wrestling, football, and others. Moreover, the number of women who have never participated in the Olympic Games for a period has been increasing continuously (33). The number of Turkish women exceeds the number of male athletes who participated in the 2012 London Olympic Games (7), this is an important indicator of the current stage view. In male-dominated football, as a result of the penalties of the teams, the filling of the tribunes by women is another striking example of the being genderless of sports.

Despite the fact that many theorists have claimed that the public space of the present day has lost its old meaning, the sport gives both the possibility to re-establish these lost relationships in the public sphere and to become a means of women to be visible in the public sphere.

In addition, behind women do more sport today, they also appear in sports, such as football, wrestling, boxing, weightlifting, bodybuilding, which are considered as men-specific sports. Although some established gender perceptions exist, the increase in women's participation in sports, men and women-specific sports is important in eliminating gender inequality (28). As a result, it is seen that the public sphere has also become significantly genderless.

\section{REFERENCES}

1. Adams NG, Bettis PJ. Liberties and Lipstick: The Paradox of Cheerleading as Sport. In: Learning Culture Through Sports: Exploring the Role of Sports in Society. Spickard Prettyman S and Lampman B, eds. Lanham, Maryland: Rowman \& Littlefield Education, 2006.

2. Amman MT. Toplumsal Boyutlariyla Cinsiyet: Sosyal, Bilimsel Yaklaşımlar. İçinde: Dini ve Toplumsal Boyutlarıyla Cinsiyet I. Tüz SA ve Kurt İ, ed. İstanbul: Ensar Neşriyat, 2012.

3. Amman MT. Kadın ve Spor. İstanbul: Morpa, 2006; $12,46,58,65$.

4. Amman MT. Spor Sosyolojisi. İçinde: Sporda Sosyal Bilimler. İkizler HC ed. İstanbul: Alfa, 2000.

5. Arendt H. İnsanlı Durumu. 7. baskı. İstanbul: İletişim Yayınları, 2013; 92-103.

6. Arslan S, Çalılık T. Yaşam boyu spor bağlamında kadınların spora yönelmesinde etkili olan unsurlar (Kırıkkale ili örneği).
Akademik Sosyal Araştırmalar Dergisi, 2018; Yıl: 6, Sayı: 76: 66-76.

7. Atalay Noordegraaf M, Çoknaz D. Türk kadın sporcuların 2012 Londra Olimpiyat Oyunları'na katılımı ve basinda yer almaları ile ilgili bir değerlendirme. International Journal of Human Sciences, 2014; 11 (2): 1351-1365.

8. Bahçeci HI. Kent mekanında kamusal alan: Richard Sennett perspektifinde bir inceleme. Memleket Siyaset Yönetim (MSY), 2018; Cilt 13, Say1 29: 111-128.

9. Berktay F. Feminist Teoride Açlımlar. İçinde: Toplumsal Cinsiyet Çalışmaları. Ecevit Y ve Karkıner N, ed. Eskişehir: Anadolu Üniversitesi Yayınları, 2011.

10. Braudel F. Uygarlıkların Grameri. 4. baskı. Ankara: İmge Kitapevi, 2014; 24.

11. Bulgu N, Koca Arıtan C, Aşçı FH. Gündelik yaşam, kadın ve fiziksel aktivite. Hacettepe Spor Bilimleri Dergisi, 2007;18 (4): 167-181.

12. Coakley JJ. Sport in Society: Issues and Controversies. 6th ed. Boston: McGraw-Hill, 1998; 211-214.

13. Defrance J. Sociologie du Sport. Paris: La Découverte, 1995: 51-52.

14. Duncan MC, Jamieson KM. Sociology of Physical Activity. In: Introduction to Kinesyology: Studying Physical Activity. Hoffman SJ, ed. Champaign: Human Kinetics, 2009.

15. Ecevit Y. Toplumsal Cinsiyet Sosyolojisine Başlangıç. İçinde: Toplumsal Cinsiyet Sosyolojisi. Ecevit Y ve Karkıner N, ed. Eskişehir: Anadolu Üniversitesi Yayınları, 2011.

16. Eitzen DS, Sage GH. Sociology of North American Sport. 6th ed. Boston: McGraw-Hill, 1997; 300.

17. Elias N, Dunning E. Quest for Excitement: Sport and Leisure in the Civilising Process. Amsterdam: University College Dublin Press, 2008; 3.

18. Emir E, Karaçam MŞ, Koca C. Kadın boksörler: Boks ringinde ve ringin dışında sürekli eldiven giymek. Hacettepe Spor Bilimleri Dergisi, 2015; 26 (4): 136-153.

19. Fasting K, Pfister G. Opportunities and Barriers for Women in Sport: Turkey. Las Wegas: Women of Diversity Productions Inc, 1999; 76-85.

20. Giulianotti R. Sport: A Critical Sociology. Cambridge: Polity Press, 2005; 86

21. Grant J. Sport, Culture and Society: An Introduction. Oxon: Routledge, 2007; 310.

22. Guttmann A. Sports: The First Five Millenia. Amherst and Boston: University of Massachusetts Press, 2004; 18.

23. Guttmann A. From Rituel to Record: The Nature of Modern Sports. New York: Columbia University Press, 2004b: 34.

24. Habermas J. Kamusallığın Yapısal Dönüşümü. 12. Bask1. İstanbul: İletişim Yayınları, 2014.

25. Hargreaves J. Sporting Females: Critical Issues in the History and Sociology of Women's Sports. London and New York: Routledge, 1994; 179.

26. Hargreaves J. Sport, Power and Culture: A social and Historical Analysis of Popular Sports in Britain. Oxford: Polity Press, 1987; 72-73,103-106. 
27. Haviland W, Prins H, Walrath D, Mcbride B. Kültürel Antropoloji. İstanbul: Kaknüs Yayınları, 2008; 313-415.

28. Kavasoğlu İ, Yaşar M. Toplumsal cinsiyet normlarının dışındaki sporcular. Hacettepe Spor Bilimleri Dergisi, 2016; 27 (3): 118-132.

29. Koca C, Bulgu N. Spor ve toplumsal cinsiyet: Genel bir bakış. Toplum ve Bilim, 2005;(103): 163-184.

30. Köroğlu CZ. Modern kamusal alana eleştirel yaklaşımlar: Genel bir değerlendirme (postmodernizm, feminizm ve din). Turkish Studies, 2013; Volume 8/6 Spring: 431-457.

31. Lumpkin, A. Introduction to Physical Education, Exercise Science and Sport Studies. 7th ed. Boston: McGraw-Hill, $2008 ; 209$.

32. Mcpherson BD, Curtis JE, Loy JW. The Social Significance of Sport. Illinois: Human Kinetics, 1989; 227-228.

33. Memiş UA, Yıldıran İ. Batı kültürlerinde kadınların spora katılımlarının tarihsel gelişimi. Gazi Beden Eğitimi ve Spor Bilimleri Dergisi, 2011; XVI (3): 17-26.

34. Messner MA. Power at Play: Sports and the Problem of Masculinity. Boston: Beacon Press, 1992; 16.

35. Outhwaite W. Kamusal Alan. İçinde: Modern Toplumsal Düşünce Sözlüğü. Outhwaite $\mathrm{W}$, ed. İstanbul: İletişim Yayınları, 2008.

36. Özbek M. Kamusal Alanın Sınırları. İçinde: Kamusal Alan. Özbek M, ed. İstanbul: Hil Yayınları, 2004.

37. Özkan D. Modern sosyal hayatta kadının toplumsal cinsiyetinin ve rollerinin dönüşümü: Geleneğe karşı modernite. Turkish Studies, 2014; Volume 9/9 Winter:12391252.

38. Öztürk P. Kadın Futbolcuların Futbol Alanındaki Deneyimleri. (Doktora Tezi), Hacettepe Üniversitesi Sağlık Bilimleri Enstitüsü Spor Bilimleri ve Teknolojisi Programı. 2017.
39. Riesman D. Yalnız Kalabalı: Amerikan Toplumunun Karakterinin Değişimi Üzerine Bir inceleme. Ankara: Heretik Yayınları, 2016.

40. Sancar S. Erkeklik. İçinde: Toplumsal Cinsiyet Çalışmaları. Ecevit $\mathrm{Y}$ ve Karkıner $\mathrm{N}$ ed. Eskişehir: Anadolu Üniversitesi Yayınları, 2011.

41. Scambler G. Sport and Society: History, Power and Culture. Berkshire: Open University Press, 2005; 15.

42. Sennett R. Kamusal İnsanın Çöküşü. 5. baskı. İstanbul: Ayrıntı Yayınları, 2016.

43. Stevenson D. Women, Sport and Globalization: Competing Discourses of Sexuality and Nation. In: Critical Readins: Sport, Culture and the Media. Rowe D, ed. Berkshire: Open University, 2004.

44. Stone GP. Some Meanings of American Sport: An Extended View. In: Aspects of Contemporary Sport Sociology. Kenyon GS, ed. Chicago: The Athletic Institute, 1969.

45. Taarruz. Eğlendirerek Hükmetmek: Halklara Karşı Kitle Kültürü. Ankara: Heretik Yayınları, 2010; 171-182.

46. Taşdelen P, Koca C. Viktorya dönemi İngilteresi'nde kadın bedeni politilakaları ve kadınların spora katılımı. Edebiyat Fakültesi Dergisi, 2015; 32 (1): 205-214.

47. Tomlinson A, Young C. Culture, Politics, and Spectacle in the Global Sports Events: An Introduction. In: National Identity and Global Sports Events: Culture, Politics, and Spectacle in the Olympics and the Football World Cup. Tomlinson A and Young C, eds. Albany: State University of New York Press, 2006.

48. Yeniçeri C. Hz. Peygamber'in Çevreciliği: Spor Etkinlikleri ve Kur'an'da Çevrecilik. 2. baskı. İstanbul: Çamlıca Yayınları, 2014; 212.

49. Yüksel M. Cinsiyet ve eğitim düzeyi eksenlerinde popüler spor branşlarındaki farklılıklar. Turkish Studies, 2015; Volume 9/5 Spring: 2201-2213.

50. Yüksel M. Cinsiyet ve spor. Tarih Okulu Dergisi, 2014; Y11 7, Sayı XIX: 663-684. 